Rev. Int. Contam. Ambie. 35 (4) 1025-1037, 2019

DOI: $10.20937 /$ RICA.2019.35.04.20

\title{
EVALUATION OF COMPLIANCE WITH REGULATORY FACTORS OF WASTE DISPOSAL SITES BY USING GEOGRAPHICAL INFORMATION SYSTEMS, CASE OF STUDY: STATE OF MEXICO
}

Evaluación del cumplimiento de factores normativos de sitios de disposición final utilizando sistemas de información geográficos, caso de estudio: Estado de México

Paulina R. CÁRDENAS-MORENO ${ }^{1}$, Ana Belem PIÑA-GUZMÁN ${ }^{1}$, Francisco J. COLOMER-MENDOZA², María del Mar CARLOS-ALBEROLA ${ }^{2}$ and Fabián ROBLES-MARTÍNEZ ${ }^{1 *}$

${ }^{1}$ Instituto Politécnico Nacional, Unidad Profesional Interdisciplinaria de Biotecnología, Departamento de Bioprocesos. Av. Acueducto s/n, Barrio La Laguna, Col. Ticomán, C.P. 07340 Ciudad de México, México

${ }^{2}$ Universidad Jaume I, Departamento de Ingeniería Mecánica y Construcción. Av. Vicente Sos Baynat s/n., 12071, Castellón, España

*Corresponding author: froblesm@ipn.mx

(Received: August 2016; accepted: February 2019)

Key words: biogas, GIS, landfill location, normativity, leachate, waste handling

\begin{abstract}
Currently, the State of Mexico (SM), the most densely populated Mexican State generates more than $19000 \mathrm{t} / \mathrm{d}$ of municipal solid waste (MSW), which is disposed in waste disposal sites (WDS). Therefore, landfill siting should consider territorial issues and legal framework to minimize negative impacts. However, the inadequate record and management at WDS makes it difficult to get precise data related to volumes, sources and composition of MSW disposed, as well as to estimate leachate and biogas emissions. The aim of this work was to determine the status of WDS in the SM, by applying a methodological approach based on the analysis of WDS location, waste handling, disposal practices, general operations, as well as the emission of biogas and leachate. Cartography of the area and geographical information systems (GIS) technology were used to generate spatial data for sites assessment, taking into account the factors and risk parameters for the operation of the WDS. Applying the assessment methodology to 83 WDS of the SM, it was determined the current situation of sites location regarding the distances from landfill location to restricted areas and their compliance with federal and state regulations established in Mexico. The findings of this study show that although the few sites properly managed as landfills receive the higher amount of waste, the vast majority of the studied sites in the SM operate improperly, generating biogas and leachate, which impact negatively on water, groundwater, air, soil and probably human health.
\end{abstract}

Palabras clave: biogás, SIG, ubicación de sitios, normatividad, lixiviados, manejo de residuos

\section{RESUMEN}

Actualmente, en el Estado de México (EM), el estado más poblado de México, se generan más de 19000 t/día de residuos sólidos urbanos (RSU) y se depositan en 
los sitios de disposición final (SDF). Por consiguiente, el emplazamiento de SDF debe considerar el marco legal y cuestiones territoriales para minimizar los impactos negativos. Sin embargo, la gestión y registros inadecuados en los SDF hace que sea difícil obtener datos precisos relativos a los volúmenes, los orígenes y la composición de los RSU dispuestos, así como para estimar las emisiones de lixiviados y biogás. El objetivo del presente trabajo fue determinar el estado de los SDF del EM, mediante la aplicación de un enfoque metodológico basado en el análisis de su ubicación, el manejo de residuos, las prácticas de disposición, las operaciones generales, así como también la emisión de biogás y lixiviados. Se utilizaron sistemas de información geográfica (SIG) y la cartografía de la zona para generar los datos espaciales para la evaluación de los sitios, teniendo en cuenta factores y parámetros de riesgo para su funcionamiento. Se evaluaron 83 SDF dentro del EM, se determinó la situación actual de su ubicación con respecto a las distancias a áreas restringidas y su conformidad con las regulaciones federales y estatales en México. Los resultados muestran que, aunque los sitios que están gestionados adecuadamente reciben la mayor cantidad de RSU, la gran mayoría de los sitios estudiados en el EM operan incorrectamente, generando biogás y lixiviados, que repercuten negativamente en las aguas superficiales y subterráneas, el aire y el suelo y probablemente en la salud humana.

\section{INTRODUCTION}

Nowadays, $70 \%$ of the municipal solid waste (MSW) collected worldwide is disposed at waste disposal sites (WDS), of which almost $40 \%$ are open dumps (D-Waste 2013). MSW must be disposed at engineering structures or landfills (Lf) in a secure manner by minimizing the impacts on the environment, however the usual way to finally eliminate MSW in developing countries is in open dumps (Colmenares-Mayanga and Santos-Bonilla 2007, Friedrich and Trois 2011, Demesouka et al. 2014). Efforts should therefore be made to avoid the non-controlled WDS and to design and construct adequately engineered Lf to minimize environmental impact.

In Mexico, the municipalities of each State are responsible for the collection and disposal of MSW, and they own special spaces to allocate the waste (Article $10^{\text {th }}$ of the LGPGIR 2003). Site selection, design, construction, operation, monitoring, closure and complementary works of a projected Lf are ruled by the Mexican Official Standard NOM083-SEMARNAT-2003 (SEMARNAT 2003), which establishes the conditions to accurately protect the environment and natural resources. Nevertheless, the performance of every WDS is different due to the applied methods of management, which often fail to fulfill the regulations and do not consider environmental and health impacts.

Besides the Government, scavengers constitute a group of people that leaders influence on the MSW management in a WDS. Scavengers are usually freelancers that are engaged in collecting recoverable materials in WDS and many of them live in landfill slums. In some controlled sites (CS) and uncontrolled sites (UCS) it can be seen scavengers living into the sites (González-Cruz 2013, Núñez-Espinoza et al. 2013, Carranza-Ramírez 2016), which represents a health issue because of the dangers to which they are exposed. Shibata et al. (2015) reported that young children living in a landfill slum were 2.87 times more likely to develop diarrhea than their general population counterparts and also suggest that landfill slum children have additional adverse health effects (e.g. infections and poisoning).

The State of Mexico (SM), the most populous state of the Mexican Republic, currently contains more than 16 million citizens (INEGI 2017). Additionally, it borders Mexico City (MC), and they constitute together the country's largest metropolitan area. SM has an area of $22499.95 \mathrm{~km}^{2}$ and is divided into 125 municipalities. In previous works (González-Cruz 2013, Cárdenas-Moreno 2014, Carranza-Ramírez 2016), serious deficiencies regarding waste management in WDS at SM were observed. This situation becomes even more relevant if we consider that in the SM approximately $12017 \mathrm{t} / \mathrm{d}$ of MSW are collected and only $25 \mathrm{t}$ of organic waste are sent to treatment facilities for recycling, whereas the rest is disposed in the SM's WDS. Moreover, in 2011, the single landfill of MC was closed after 25 years of operation. Consequently, four WDS in the SM began receiving $7349 \mathrm{t} / \mathrm{d}$ of MSW coming from MC, increasing the volumes of MSW usually arranged (SEDEMA 2014).

To minimize the environmental effects of the rising generation and the inadequate management of waste, a major effort must be made implementing efficient methods of disposal and verifying 
constantly that WDS comply regulations, including all the regulations and the standards stated at the NOM-083-SEMARNAT-2003 (SEMARNAT 2003). In this sense, searching for suitable landfill location is a complex process that must combine social, environmental and technical aspects, as well as taking into account the location restrictions stated in normative instruments. This important task clearly requires processing a huge amount of geospatial data. Regarding MSW disposal locations, some authors have used Geographic Information Systems (GIS), a tool to overlay different attributes of an area on a map. Zamorano et al. (2008), Marín et al. (2012) and Gbanie et al. (2013), used GIS to identify suitable locations for such facilities. Gallardo et al. (2014) used GIS to create a helpful tool to design MSW collection routes. Moreover, Colomer-Mendoza et al. (2013) used GIS to analyze the degree of compliance of Spanish Lf regarding environmental factors, proposing a methodology to optimize the location of the Lf according to Spanish laws. An important component is the GIS software that allows handling a large number of spatial parameters (geographic information and related data) and performing complex analysis. Several software tools are used for GIS, but the usually used in the study of waste management is ArcGIS $^{\mathrm{TM}}$ (Gallardo-Izquierdo and Bernard-Beltrán 2011).

Based on the use of GIS in the field of waste management, the objective of the present study was to determine the status of the WDS in SM. This was carried out through a methodological approach considering the analysis of the location, the MSW management, the general operations, as well as the emission of biogas and leachate using digital cartography of the studied area.

\section{PROCEDURE}

A preliminary methodological approach was proposed (Fig. 1) to establish the environmental impact assessment of any WDS in a territory, verifying the level of compliance with some aspects of the current regulations.

The first step was to select the SM as the study area, because of the large number of WDS in it and the problems of MSW management arising in the zone. Subsequently, the region where the WDS are located was defined in order to delimit the scope of the investigation. Its geographical location and the parameters and factors related where also defined.

The considered parameters of this study were the risk factors involved in the WDS operation, as well as the affected components and those influencing the operation and maintenance of sites. Table I shows the list of analyzed parameter of the WDS studied. The number of the parameters considered is not a fixed number, but depending on the available information, the table may contain more or less elements. Regarding the location of Lf, the requirements of Mexican regulations (NOM-083-SEMARNAT-2003) were considered, trying to find an optimal distance towards the population centers that minimizes both the possible annoyances and the cost of the waste transport.

The information about the WDS considered for this study was obtained from several primary, secondary and tertiary sources.

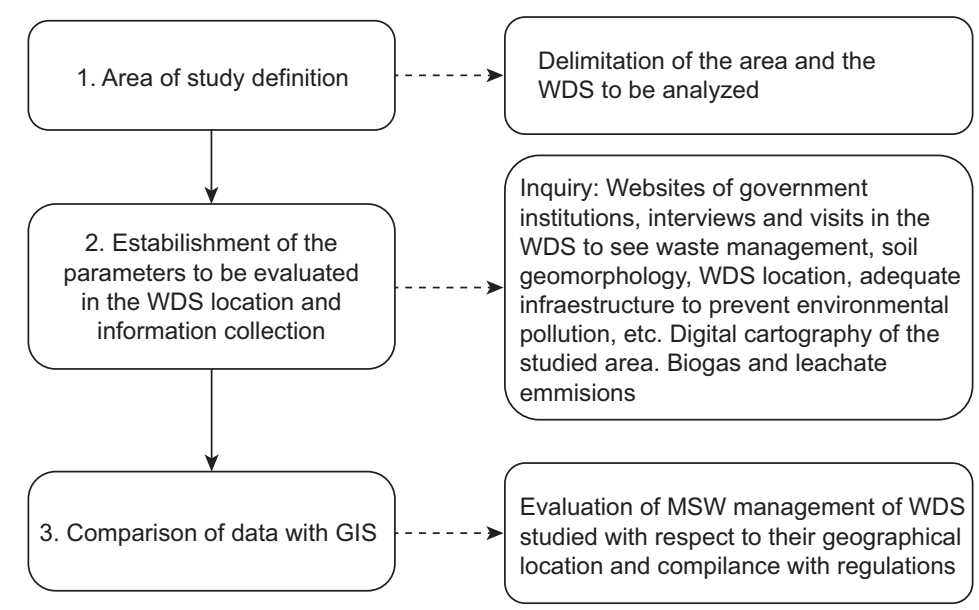

Fig. 1. Flow diagram to establish the preliminary evaluation of a WDS environmental impact. 
TABLE I. ANALYZED FACTORS AT THE LANDFILL LOCATION AND OPERATION

\begin{tabular}{|c|c|}
\hline Parameter & Concept \\
\hline a) Waste management & $\begin{array}{l}\text { Amount of waste received } \\
\text { Type of management of the received MSW } \\
\text { Number of inhabitants in the municipality } \\
\text { Landfill lifespan } \\
\text { Available area } \\
\text { MSW coverage, material volatility and odor prevention }\end{array}$ \\
\hline b) Landfill location & $\begin{array}{l}\text { Distance from population centers } \\
\text { Distance from airports } \\
\text { Distance from rivers, streams, torrents underground waters } \\
\text { Distance from NPA }\end{array}$ \\
\hline c) Geomorphology and soil & $\begin{array}{l}\text { Soil permeability (texture and structure) } \\
\text { Changes in the area, displacements, gliding, subsidence, etc. }\end{array}$ \\
\hline $\begin{array}{l}\text { d) Accurate infrastructure to } \\
\text { prevent environmental pollution }\end{array}$ & $\begin{array}{l}\text { Infrastructure for biogas emission management } \\
\text { Infrastructure for leachate emission management }\end{array}$ \\
\hline e) Biogas emissions & $\begin{array}{l}\text { Air quality, biogas estimates by MSW disposed at site (organic matter } \\
\text { degradation) }\end{array}$ \\
\hline f) Leachate production & Estimation of organic matter degradation, rain, climate, leachate infiltration \\
\hline g) Employees on the site & $\begin{array}{l}\text { Formal salaried workers } \\
\text { Scavengers }\end{array}$ \\
\hline h) Landscape & Visual impact \\
\hline i) Healthiness & $\begin{array}{l}\text { Presence of carriers of enteric pathogens such as rodents, insects, birds and } \\
\text { larger wild mammals and other potential carriers of communicable diseases }\end{array}$ \\
\hline j) Forest fires & As a consequence of the WDS activity \\
\hline k) Technology innovation & Technology improvements \\
\hline
\end{tabular}

$\mathrm{MSW}=$ municipal solid waste, $\mathrm{NPA}=$ natural protected areas

Regarding the waste management, it was difficult to find reliable information on websites. Some government agencies have information, but not enough, so it was necessary to conduct field visits in the study areas to collect the data. The primary sources were related to the WDS operators, the information was obtained through surveys and interviews. The secondary sources were sources such as public institutions, government portals, scientific articles, etc. Finally, the tertiary sources provided information published in unofficial websites as well as those reported by González-Cruz (2013) and Núñez-Espinoza et al. (2013). Finally, using ArcMap 10.2 ${ }^{\mathrm{TM}}$, different layers with geo-referenced parameters of WDS were overlaid to display sites information in order to assess their locations, regarding compliance with the Mexican standard (NOM-083-SEMARNAT-2003). The 83 WDS were mapped and presented in maps, which were developed in order to visualize the geographic distribution of WDS and to determine important issues related to sitting and management, as well as to make evident the compliance with regulations of such WDS.

\section{Study case application \\ Study area identification}

The SM is located in the center/south of the country, between parallels $18^{\circ} 21^{\prime}$ and $20^{\circ} 17^{\prime}$ north latitude and $98^{\circ} 36^{\prime}$ and $100^{\circ} 36^{\prime}$ west longitude. The annual average rainfall is $900 \mathrm{~mm}$ and the average temperature is $15^{\circ} \mathrm{C}$. In the study area, 83 WDS were addressed.

\section{Collection of information about parameters to assess}

As a basis for the analysis, information of 83 WDS located in the SM, which represent $66 \%$ of the municipalities of the state, was obtained from 
González-Cruz (2013) and from the website "Red Residuos del Valle de México" (Núñez-Espinoza et al. 2013) regarding the main characteristics (daily tonnage received from MSW, type of management that are operated, geographical location, etc.). Such information was gathered by González-Cruz (2013) through visits and interviews with the people responsible for the WDS. On the one hand, statistics related to generation, management and disposal of MSW, as well as the cartography of the study area regarding populations, communities, land use, roads, hydrography, topography and political division were obtained from the websites of government institutions (CONABIO 2012, CONAGUA 2012, INEGI 2014).

The gathered data was saved into a geo-referenced database to integrate them with the cartography obtained on a GIS and was used for evaluating seven of the eleven parameters proposed in table I (parameters from a to g). The rest of the parameters were not evaluated in this paper because information about was not available or was incomplete.

\section{WDS location \\ Minimum distances from restricted areas}

NOM-083-SEMARNAT-2003 (SEMARNAT 2003) establishes the minimum distances between the Lf and the human settlements, airports, superficial and underground running waters and natural protected areas (NPA) (Table II). For the evaluation of this parameter, the distance from WDS to the mentioned areas was measured using ArcMap 10.2 and their compliance with Mexican standards was determined.

\section{Soil geomorphology}

According to Del Pozo-Manrique (1991), the type of soil where a $\mathrm{Lf}$ is located allows defining its level of long-term hydrogeographical safety, and any hydrogeographically-vulnerable area is not allowed. In order to identify hydrogeological site conditions, SM was divided according to the geomorphology of the ground (using the layer of types of soils from INEGI (2018)). Afterwards, the very permeable soils such like sedimentary soils with a large amount of intergranular permeability, karstificable materials, (limestone, dolomites, gypsum) and rocks with fissure permeability (mainly igneous and metamorphic) were identified in order to evaluate where the WDS were located using ArcMap 10.2.

\section{Site operation}

To evaluate this parameter, the Mexican Official Standard NOM-083-SEMARNAT-2003 was taken into account, where WDS are categorized in: i) landfill (Lf), ii) controlled sites (CS) and iii) uncontrolled sites (UCS) or open dumps, according with

TABLE II. SUMMARY OF THE WASTE DISPOSAL SITES THAT COMPLY THE DISTANCES WITH SENSITIVE AREAS (NOM-083-SEMARNAT-2003).

\begin{tabular}{|c|c|c|c|c|c|}
\hline WDS location factor & NOM-083 & $\begin{array}{l}\text { WDS that } \\
\text { fulfill }(\%)\end{array}$ & $\begin{array}{l}\text { Deposited } \\
\text { MSW (\%) }\end{array}$ & $\begin{array}{l}\text { WDS that do } \\
\text { not fulfill }(\%)\end{array}$ & $\begin{array}{c}\text { Deposited MSW } \\
(\%)\end{array}$ \\
\hline $\begin{array}{l}\text { Distance from human } \\
\text { settlements }\end{array}$ & $>0.5 \mathrm{~km}$ & $\begin{array}{l}66(80 \%) \\
14 \mathrm{Lf} \\
18 \mathrm{CS} \\
34 \mathrm{UCS}\end{array}$ & 60 & $\begin{array}{l}17(20 \%) \\
7 \mathrm{Lf} \\
5 \mathrm{CS} \\
5 \mathrm{UCS}\end{array}$ & 40 \\
\hline Distance from airports & $>13 \mathrm{~km}$ & $\begin{array}{c}76(92 \%) \\
17 \mathrm{Lf} \\
23 \mathrm{CS} \\
36 \mathrm{UCS}\end{array}$ & 79 & $\begin{array}{c}7(8 \%) \\
4 \mathrm{Lf} \\
3 \mathrm{UCS}\end{array}$ & 21 \\
\hline $\begin{array}{l}\text { Distance from rivers, } \\
\text { streams, torrents and } \\
\text { underground waters }\end{array}$ & $>0.5 \mathrm{~km}$ & $\begin{array}{l}64(77 \%) \\
14 \mathrm{Lf} \\
20 \mathrm{CS} \\
30 \mathrm{UCS}\end{array}$ & 59 & $\begin{array}{l}19(23 \%) \\
7 \mathrm{Lf} \\
3 \mathrm{CS} \\
9 \mathrm{UCS}\end{array}$ & 41 \\
\hline $\begin{array}{l}\text { Distance from NPA, } \\
\text { Sanctuaries and WA }\end{array}$ & $\begin{array}{l}\text { Should not } \\
\text { be in }\end{array}$ & $\begin{array}{l}68(83 \%) \\
18 \mathrm{Lf} \\
19 \mathrm{CS} \\
31 \mathrm{UCS}\end{array}$ & 80 & $\begin{array}{l}15(17 \%) \\
3 \mathrm{Lf} \\
4 \mathrm{CS} \\
8 \mathrm{UCS}\end{array}$ & 20 \\
\hline
\end{tabular}

$\mathrm{WDS}=$ waste disposal sites, $\mathrm{MSW}=$ municipal solid waste, $\mathrm{NPA}=$ natural protected areas, $\mathrm{WA}=$ wooded areas, $\mathrm{Lf}=$ landfills, $\mathrm{CS}=$ controlled sites, $\mathrm{UCS}=$ uncontrolled sites 
waste handle and disposal practices. The Lf are the only sites operated properly as they compact and cover their MSW daily, moreover, they have infrastructure to prevent contamination of soil, ground water (impermeable barrier or geomembrane) and air (venting wells and biogas burners). CS have a management partially good, because they comply with almost all the specifications of the NOM083-SEMARNAT-2003, but they do not have geomembrane. UCS operate improperly, because they do not fulfill any requirement of the standard. In turn, according to the tonnage of MSW received daily, Lf and CS can be categorized as A1: receiving more than $750 \mathrm{t} / \mathrm{d}$; A2: receiving $100-750 \mathrm{t} / \mathrm{d}$; B: receiving $50-100 \mathrm{t} / \mathrm{d}$; $\mathrm{C}$ : receiving $10-50 \mathrm{t} / \mathrm{d}$ and $D$ : receiving less than $10 \mathrm{t} / \mathrm{d}$.

Also, because of the influence of employees in site operation, it was asked about how many and what kind of employees (formal workers or scavengers) there were on the sites.

\section{Accurate infrastructure to prevent environmental pollution by biogas and leachate emissions}

For this item, it was checked if the Lf had an evacuation infrastructure for recovering or burning the biogas generated. It was also analyzed if the site counted on a waterproofing system or geomembrane to avoid leachate migration towards the subsoil.

The emission of biogas in the 83 studied WDS was estimated by using the Version 2.0 of the Mexican Model of Biogas (MMB), which uses the equation of first order decay for degradation (Eq. 1). This equation assumes that biogas production reaches its top after a determined period after the deposit of waste. The equation calculates biogas production by using accumulated disposed amounts of waste throughout a year (US-EPA and SCS 2009).

$Q_{L F G}=\sum_{t=1}^{n} \sum_{j=0.1}^{1} 2 k L_{0}\left[M_{i} / 10\right] \exp \left(-k t_{i j}\right)(M C F)(F)$

Where $Q_{\mathrm{LFG}}$ is the maximum expected biogas flow; $i$ is the annual increment; $n$ is the difference between the year of the calculation and the year of waste initial disposal; $j$ is the time increment at 0.1 years old; $M i$ is the mass of waste disposed throughout the year $i$; and $t_{\mathrm{ij}}$ is the age of section $j$ of the waste mass $M i$ disposed in the year i. MCF is the methane correction factor, a value that depends on the depth and type of WDS, and $F$ is the adjustment factor for fire, $k$ is the rate of generation of methane and its value depends on the moisture content, the nutrient availability, the $\mathrm{pH}$ and the temperature in the $\mathrm{Lf}[1 / \mathrm{yr}] ; L_{0}$ is the methane generation potential $\left[\mathrm{m}^{3} / \mathrm{t}\right]$. The $L_{0}$ and $k$ values depend on the climate zone where the site is located and the speed of degradation of the waste. Finally, the amount of $\mathrm{CH}_{4}$ is multiplied by two because it is assumed that biogas composition is about $50 \% \mathrm{CH}_{4}$ and $50 \% \mathrm{CO}_{2}$. The years of opening and closing of the site, the annual MSW provision, type of management, height, among other information (listed in US-EPA and SCS 2009) should be provided in the Excel® spreadsheet that the model uses.

Moreover, the Water Balance Method (Fenn et al. 1975) uses equation 2 to perform an estimate of the potential amount of generated leachate in each of the studied sites.

$L_{0}=[\mathrm{I}-\mathrm{E}] A-a W$

Where $L_{0}$ corresponds to the leachate production $\left(\mathrm{m}^{3} / \mathrm{yr}\right) ; I$ is the total entrance of liquids (precipitations, liquid from MSW and underground waters) [m/ $\mathrm{yr}] ; E$ is the loss of water because of evapotranspiration $[\mathrm{m} / \mathrm{yr}] ; A$ is the site area $\left[\mathrm{m}^{2}\right] ; a$ is the absorption capacity of the received MSW and $W$ is the volume of disposed MSW [ $\left.\mathrm{m}^{3} / \mathrm{yr}\right]$.

Other considerations were also taken into account to calculate the emissions of leachate. For example, it was considered that average annual precipitation of SM is $0.9 \mathrm{~m}$ (INEGI 2017). The initial humidity content was considered from Kiss-Köfalusi and Encarnación-Aguilar (2006) data that pointed out a value of $37 \%$ for MSW in Mexico. The specific weight of MSW according to the management varies from 451 to $600 \mathrm{~kg} / \mathrm{m}^{3}$, the amount of consumed water in decomposition reactions is $7.378 \mathrm{~kg} \mathrm{H}_{2} \mathrm{O}$ / $\mathrm{m}^{3}$ biogas and the amount of water lost as vapor is $0.30 \mathrm{~kg}$ of $\mathrm{H}_{2} \mathrm{O} / \mathrm{m}^{3}$ of produced biogas (Tchobanoglous 1998).

Finally, the results obtained with both models were projected in intervals of values with Arcmap 10.2 (Fig. 2 and Fig. 3).

\section{RESULTS AND DISCUSSION}

The results of this study refer to several important parameters that have been analyzed such as the site operation, the soil and the geomorphology, the WDS location, the infrastructure to prevent environmental pollution, and biogas and leachate emissions.

\section{WDS location}

The distances from each of 83 WDS to restricted zones were determined and the compliance with the 


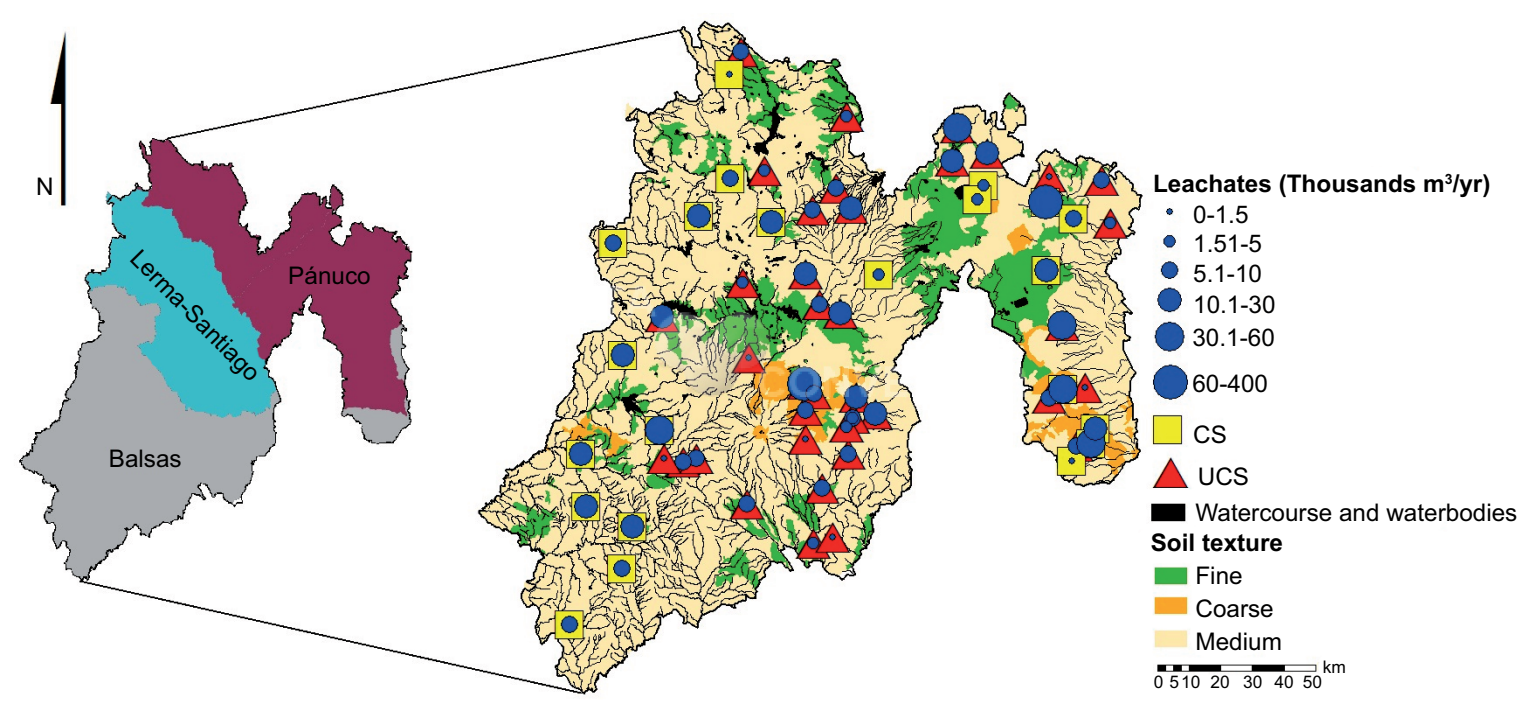

Fig. 2. Leachate generation estimated for 2015, geology and hydrography of the State of Mexico

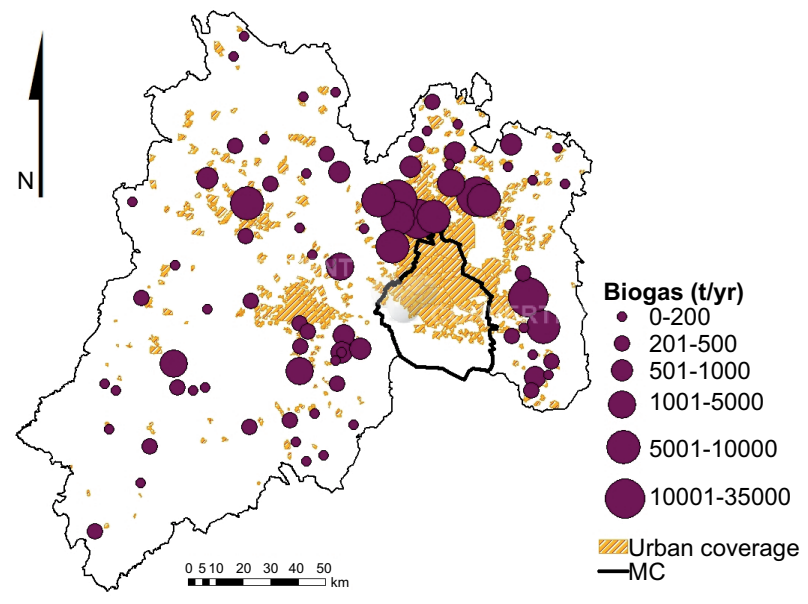

Fig. 3. Biogas flow in WDS estimated for year 2015 by using MMB.

Mexican Regulation was verified. In general, more than $70 \%$ of the WDS are located at correct distances (Table II). According to NOM-083-SEMARNAT-2003, a Lf must be located at a distance greater than $0.5 \mathrm{~km}$ from human settlements, rivers, streams, torrents and underground waters. The SM has more than 922000 ha of NPA, sanctuaries and wooded areas (WA), and it was verified that 15 WDS (17\%) are located less than $500 \mathrm{~m}$ away from such areas where animals and plants can be exposed to the pollutants produced in WDS. Still more relevant is the finding that 17 and 19 sites are located $500 \mathrm{~m}$ or less from human settlements and from surface water, respectively.
Concerning distance to airports, it was found that six WDS (7\%) are located within a distance of $13 \mathrm{~km}$ from the three airports in the SM (Table II), which represents a risk, as there may be light materials or birds moving in the air that could obstruct vision and operation of the aircraft in flight. The geographical location of the WDS to the restricted zones are shown in figure 4.

\section{Soil geomorphology}

The permeability of the soil is associated to its texture, the lower the particle diameter the smaller the filtration is. When the permeability of soil is high, the liquid filtration is also high. Therefore, when any type of pond must be built on this kind of soil, geomembranes must be placed to prevent the filtration of liquids towards underground. Therefore, it is recommended to locate $\mathrm{Lf}$ in clay soils due to its low permeability and to avoid sandy soils. According to the particle size and the texture of soil, the cartographic plans of the SM published by INEGI (2018) show 20 soil types classified as fine-, medium- and coarse-textured soils according to Wicander et al. (2008) (Table III).

Integrating such information in figure 2, it is shown that eight WDS $(10 \%)$ are in fine-textured soils; 63 (76\%) in medium-textured soils and 12 $(15 \%)$ in coarse-textured soils. Therefore, there is a risk of contamination of groundwater by leachate from $75(90 \%)$ of the total WDS, which are in permeable or semi-permeable soils. Unfortunately, only 19 (17 Lf and two CS) have a waterproof barrier at the base of the site. In the rest of sites located 


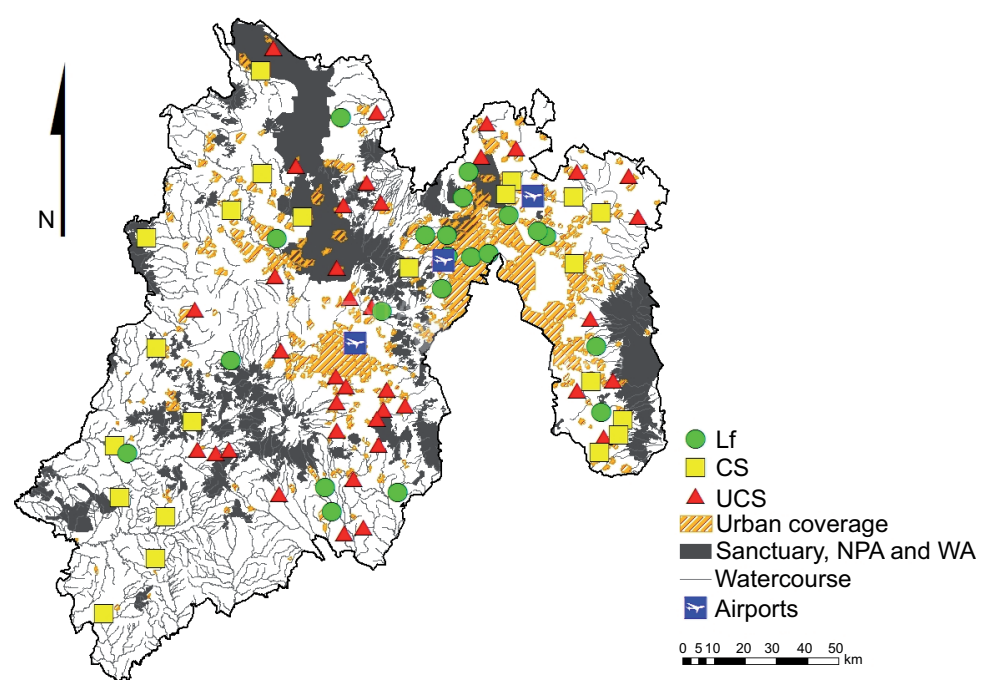

Fig. 4. WDS location from restricted areas: Populations, NPA and airports.

in this type of soil, there is a great risk that leachate migrates towards water bodies. The model used in this study estimated that Lf, compared with CS and UCS, generate higher volumes of leachate because of the high percentage of MSW disposed. However, this model do not consider the type of site, therefore minimizing precipitation effects on the volume of leachate generated, since CS and UCS do not cover the waste daily and water easily leaks into the discharge cells. Despite the low estimated volume of leachate, it may contain volatile acids, fats and heavy metals, among others (Tchobanoglous 1998, Robles-
Martínez 2008), which are harmful to human health, even at low concentrations, and could be retained on the ground or water for long periods and it can be difficult to remove them.

The SM has three of the 37 hydrographic regions in which the country is divided. There are three river basins in the SM: Lerma-Santiago, Balsas and Pánuco (Fig. 2). These hydrographic regions provide water not only to the SM but also for Mexico City (CONAGUA 2012). This is relevant to the concentration of population and the economic activities that take place in this state. Figure 2 shows the water bodies

TABLE III. SOIL TYPES IN STATE OF MEXICO AND PERMEABILITY BASED ON SOIL TEXTURE.

\begin{tabular}{lcc}
\hline $\begin{array}{l}\text { Soil type } \\
\text { (INEGI 2014) }\end{array}$ & $\begin{array}{c}\text { Texture } \\
\text { (Wicander et al. 2008) }\end{array}$ & Type of WDS \\
\hline Pellic and chromic Vertisol & Fine (Low permeability) & 4 Lf; 1 CS; 3 UCS \\
\hline $\begin{array}{l}\text { Humic mollic and ochric Andosol } \\
\text { Calcic and eutric Cambiosol }\end{array}$ & & \\
$\begin{array}{l}\text { Haplic and luvic Frozem } \\
\text { Lithosol }\end{array}$ & Medium & 16 Lf; 17 CS; \\
Chromic Luviosol & (Medium & 30 UCS \\
$\begin{array}{l}\text { Eutric and mollic Planosol } \\
\text { Eutric Regosol }\end{array}$ & permeability) & \\
Rendzina & & $1 \mathrm{Lf}, 5 \mathrm{CS} ;$ \\
\hline $\begin{array}{l}\text { Dystric Fluvisol } \\
\text { Dystric and eutric Regosol }\end{array}$ & Coarse \\
$\begin{array}{l}\text { Regosol } \\
\text { Haplic Frozem }\end{array}$ & (High & \\
\hline
\end{tabular}

$\mathrm{Lf}=$ landfills, $\mathrm{CS}=$ controlled sites, $\mathrm{UCS}=$ uncontrolled sites 
(lakes, streams and rivers) in the SM, as well as the estimated potential generation of leachate from CS and UCS. As in Lf leachate is confined in evaporation ponds or receive any other treatment, these sites were not considered in this figure.

Although $77 \%$ of the WDS are located more than $500 \mathrm{~m}$ away from rivers or water bodies as stated by the Mexican standard, $69 \%$ of the sites do not have any barrier to protect the subsoil and groundwater aquifer from leachate migration. WDS without a geomembrane is an ongoing problem with high potential to contaminate surface and groundwater. It is necessary to know the magnitude that this represents, however, to stop the constant contamination of the medium, cleaning and regulating all the sites by implementing the necessary infrastructure according to the standard must be accomplished.

\section{Waste management}

Around 13148 t of MSW were dumped daily in the 83 WDS reported in this paper. It is important to mention that the difference between data reported by INEGI (2012) (12 $017 \mathrm{t} \mathrm{MSW/d)} \mathrm{and} \mathrm{our} \mathrm{obtained}$ data (13 $148 \mathrm{t} \mathrm{MSW/d)}$ is due to the source of information (secondary vs. primary source, respectively). Nevertheless, almost $75 \%$ of the WDS (23 CS and 39 UCS) were sites poorly operated, where only $20.5 \%$ of the total MSW (2700 t/d) was disposed; whereas $25 \%$ of surveyed sites are Lf where $79.5 \%$ of MSW $(10448 \mathrm{t} / \mathrm{d})$ was disposed (Fig. 5). It means that the vast majority of MSW is disposed in Lf properly managed. Moreover, seven from the $21 \mathrm{Lf}(33 \%)$ are type $\mathrm{A} 1$, six $(29 \%)$ are type $\mathrm{A} 2$, one $(5 \%)$ is type B, four (19\%) are type C and three (14\%) are type D. In contrast, from the $23 \mathrm{CS}$ founded (28\%), one was type A2, four were identified as type B, 11 as type $\mathrm{C}$ and seven as type D. Finally, the 39 UCS identified (47\%), cannot be classified as established

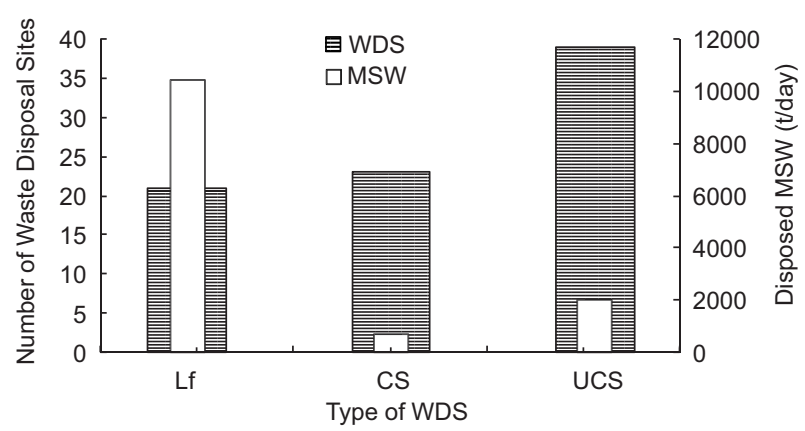

Fig. 5. Amount of WDS and disposed daily tonnage according to the type of site. by NOM-083-SEMARNAT-2003 because of the lack of records of its disposed waste volumes. However, according to the information provided by the managers of UCS, it was estimated that $1998.8 \mathrm{t}$ of MSW is dumped daily on such sites.

Besides, it was found that in 64 sites $(77 \%)$ the coverage of waste is carried out, but the daily covering (as stated by Mexican regulation) is performed only in 26 sites (21 Lf and $5 \mathrm{CS}$ ). Therefore, all the rest of sites largely contribute to the flight of materials and dispersion of odors. Regarding the fence around the landfill perimeter, which is also stated by NOM083-SEMARNAT-2003, only 24 from 83 WDS (29\%) count with such device, that allows to control the entry of any type of waste (including hazardous waste), as well as scavengers and certain species of vermin injurious fauna.

\section{Employees at the sites}

In the studied WDS, there were found formal salaried workers as well as scavengers. The formal employees are people that works at the sites and receive remuneration by the management of each site (operators of the machinery, administrative staff, etc.), and scavengers are people entirely independent to sites and do not have any salary or contract with the WDS administration. As expected, up to $80 \%$ of CS and UCS does not restrict the access to informal workers and there is not a formal manager, but only scavengers are engaged in the collecting of recoverable materials. Also, it was found that even if the NOM-083-SEMARNAT-2003 prohibits the presence of informal workers in Lf, $43 \%$ of this category of sites permit the access to scavengers. Therefore, as scavengers neither possess personal protective equipment nor receive medical service, they are exposed to the gases and toxic compounds that may be present at the sites (mainly at UCS). In general, there is no concrete data on how many scavengers exist per site, however the ratio of them increases with the size of the site.

\section{Accurate infrastructure to prevent environmental pollution by biogas and leachate emissions}

According to Mexican regulation, a Lf must fulfill some operational and infrastructure standards to avoid that the MSW degradation products pollute the environment. All $21 \mathrm{Lf}$ studied in this work fulfill requirements. On the other hand, $11 \mathrm{CS}$ have the required infrastructure to manage biogas (39\% WDS) while only five CS for leachate (31\% WDS) (Table IV). Probably, these CS could have operated as Lf at the beginning, but by some issue, they lost 
TABLE IV. WASTE DISPOSAL SITES' COMPLIANCE WITH MEXICAN ENVIRONMENTAL REQUIREMENTS REGARDING INFRASTRUCTURE TO PREVENT POLLUTION (NOM-083-SEMARNAT-2003)

\begin{tabular}{lcccc}
\hline Required infrastructure & $\begin{array}{l}\text { WDS that } \\
\text { fulfill (\%) }\end{array}$ & $\begin{array}{c}\text { Disposed } \\
\text { MSW \% }\end{array}$ & $\begin{array}{r}\text { WDS that do } \\
\text { not fulfill (\%) }\end{array}$ & $\begin{array}{c}\text { Disposed } \\
\text { MSW \% }\end{array}$ \\
\hline For biogas emission management & $32(39 \%)$ & 84 & $51(61 \%)$ & 16 \\
\hline $\begin{array}{l}\text { For leachate emission management } \\
\text { geomembrane/leachate lagoons) }\end{array}$ & $26(31 \%)$ & 80 & $57(69 \%)$ & 20 \\
\hline
\end{tabular}

WDS $=$ waste disposal sites, $\mathrm{MSW}=$ municipal solid waste

control of the site representing not only economic losses by the investment made but also become liable to penalties and fines. In the NOM-083-SEMARNAT-2003 is stated that the extraction, collection, handling and control of biogas and leachate from the site of final disposal must be guaranteed. In order to ensure oxidation and to minimize the emissions of methane, it must be implemented a system consisting of individual wells to take advantage of biogas or a network with a central biogas burner. Regarding leachate, it must be recovered and treated. Another option is to install a recirculation system that returns leachate to cells.

Besides the $21 \mathrm{Lf}$, there are CS that have the infrastructure to prevent pollution by both leachate and biogas, however, such sites cannot be classified as Lf, because they do not fulfill other requirements (soil recovery and waste compaction) stated in NOM083-SEMARNAT-2003.

Table $\mathbf{V}$ shows the summarized results obtained for biogas generation with MMB for two years and leachate generation using the water balance method for one year. As expected, the greater amount of waste the greater the generation of biogas and leachate due to degradation of the organic fraction, which is over $50 \%$ for the MSW from SM (INEGI 2012). The flow of leachate was estimated for each WDS studied, where such flows were in the range of 10 to 200 million L/yr. The WDS receiving more than $100 \mathrm{t} / \mathrm{d}$ generate the higher volumes of leachate. The different volumes produced by sites are primarily due to the quantity and composition of disposed MSW and to the area of the WDS.

On the other hand, the most populous metropolitan area of Mexico comprises the region of MC surrounded largely by the SM, and both entities concentrate more than 23 million citizens in densely populated urban areas (Fig. 3). Therefore, for the country and the municipalities, it should be a great commitment to monitor and to process the effluents (biogas and leachate) from the WDS located in this big area as well as to prevent accidents and diseases among residents. As depicted in figure 3, the Lf located at the municipalities surrounding MC (i.e. Atizapán de Zaragoza, Nicolás Romero, Cuautitlán Izcalli, Tlalnepantla, Ixtapaluca, Tlalmanalco and Ecatepec), are the highest biogas producers. This brings a negative impact on the environment and the health of the inhabitants from this metropolis, since much of this biogas passes through the urban area, due to the movement of the air currents from north to south in this region.

It is known that each of the seven most populous municipalities in the SM, located closest to MC

TABLE V. BIOGAS PRODUCTION FLOW ESTIMATED WITH MMB FOR DIFFERENT TYPES OF WASTE DISPOSAL SITES IN 2015 AND 2020

\begin{tabular}{|c|c|c|c|c|c|c|c|c|}
\hline \multirow{2}{*}{$\begin{array}{l}\text { WDS } \\
\text { type/yr }\end{array}$} & \multirow{2}{*}{$\begin{array}{c}\text { MSW } \\
(\mathrm{t} / \mathrm{d})\end{array}$} & \multirow{2}{*}{$\%$} & \multicolumn{4}{|c|}{ Biogas flow (t/yr) } & \multicolumn{2}{|c|}{ Leachate flow $\left(\mathrm{m}^{3} / \mathrm{yr}\right)$} \\
\hline & & & 2015 & $\%$ & 2020 & $\%$ & 2015 & $\%$ \\
\hline Lf & 10448.11 & 80 & 125899.05 & 83 & 155220.20 & 86 & 1717542.96 & 61 \\
\hline $\mathrm{CS}$ & 701.20 & 5 & 5842.25 & 4 & 4481.99 & 3 & 405127.32 & 15 \\
\hline UCS & 1998.84 & 15 & 20466.84 & 13 & 13606.21 & 11 & 681845.63 & 24 \\
\hline Total 83 & 13148.15 & 100 & 152208.14 & 100 & 173308.4 & 100 & 2804515.91 & 100 \\
\hline
\end{tabular}

$\mathrm{WDS}=$ waste disposal sites, MSW $=$ municipal solid waste, $\mathrm{Lf}=$ landfills, $\mathrm{CS}=$ controlled sites, $\mathrm{UCS}=$ uncontrolled sites 
(receiving more than $100 \mathrm{t} / \mathrm{d}$ ) have a Lf with biogas collection and flare systems. However, other adjacent municipalities that have WDS do not have leachate collection or biogas burning systems, which facilitates that most of the biogas generated by these sites would be dispersed into the atmosphere.

Such dispersion of the pollutants is complicated due to in MC the surface wind flow is influenced by the wind flow at low and high levels of the troposphere. During the wet season (summer), the flow has a strong north component across the valley. On the other hand, the dry season has as an important feature a vortex (whirlpool) formed near the center of $\mathrm{MC}$, which is due to the effect known as "heat island"; a meteorological situation generated by the increased soil temperature of the urban zone, with building materials of concrete and asphalt, in contrast to the surrounding forest areas. Graphic information about this can be found in SEDEMA (2006). Moreover, these flows from the north of the valley bring suspended particles as well as the biogas generated in WDS that surround MC. This issue is being addressed in another study on the way.

With all those data, a document could be drawn up that provides information regarding WDS in SM. This document could be useful to support the compliance of each Lf with the regulations and could make it easier to take decisions in terms of future actions on such sites.

\section{CONCLUSIONS}

This case study analysis highlights that only $25 \%$ of waste disposal sites in the State of Mexico are landfills, and the rest (75\%) are either controlled sites (28\%) or uncontrolled sites (47\%), both operating improperly, according to federal rules, and therefore lacking imperative environmental controls. Although the highest amount $(79.5 \%)$ of waste generated in the most populous metropolitan area of Mexico is disposed in well-operated landfills where high volumes of biogas and leachate are well managed, a still relevant bulk of waste is improperly managed.

The use of GIS tools enabled to easily determine the location of WDS, in order to assess whether they comply with the regulations with respect to the distances established to restriction zones, as well as the type of soil where the WDS were located and the projection of the biogas and leachate flow. Regarding sites location, it was found that more than $60 \%$ of the studied WDS comply the specified limit distances from restricted areas as stated in Mexican regulations. Therefore, there is a risk of contamination of groundwater and subsoil by leachate from the CS and UCS, due to the fact that 57 WDS $(69 \%)$ do not have a waterproof barrier at the base of the site, in spite of $90 \%$ of the total WDS are in permeable or semi-permeable soils. Also, there are some municipalities adjacent to MC, that have WDS without systems to leachate collection or biogas burning, which facilitate the biogas generated at these sites be dispersed into the atmosphere.

Still, the level of compliance in a waste disposal site should be total (with environmental and health protection), therefore, it should be carried out a high level of constant monitoring regarding location, waste handling, disposal practices, general operations, as well as the emission of biogas and leachate, in order to observe the evolution of the degree of compliance.

\section{REFERENCES}

Cárdenas-Moreno P.R. (2014). Estimación de biogás y lixiviados generados en sitios de disposición final de residuos sólidos urbanos del Estado de México. Tesis de Maestría. Unidad Profesional Interdisciplinaria de Biotecnología, Instituto Politécnico Nacional. Mexico City, Mexico, 103 pp.

Carranza-Ramírez C. (2016). Estado actual de la disposición de los residuos sólidos urbanos en los municipios de la zona oriente del Estado y valle de México. Tesis de Licenciatura. Unidad Profesional Interdisciplinaria de Biotecnología, Instituto Politécnico Nacional. Mexico City, Mexico, 63 pp.

Colmenares-Mayanga W. and Santos-Bonilla K. (2007). Generacion y manejo de gases en sitios de disposición final [online]. http://www.ingenieriaquimica.org/system/files/relleno-sanitario.pdf 22/05/15

Colomer-Mendoza F.J., García-Darás F., Vives-Peris V. and Robles-Martínez F. (2013). Aspectos ambientales a considerar en vertederos: Emplazamiento y emisiones de biogás. DYNA 88 (1), 726-730.

DOI. 10.6036/DYNAII

CONABIO (2012). Portal de goinformación sistema nacional de información sobre biodiversidad. Comisión Nacional para el Conocimiento y uso de la Biodiversidad [online]. http://www.conabio.gob.mx/informacion/gis/ $15 / 04 / 2015$

CONAGUA (2012). Atlas digital del agua México 2012. Comisión Nacional del Agua [online]. http://www. conagua.gob.mx/atlas/ 16/05/2015

D-Waste (2013). Waste atlas 2013 report. D-Waste [online]. https://www.iswa.org/fileadmin/galleries/News/ WASTE_ATLAS_2013_REPORT.pdf 30/03/2017 
Del Pozo-Manrique M. (1991). Selección de emplazamientos para vertederos controlados. Inf. Constr. 42 (412), 23-40. DOI: 10.3989/ic.1991.v42.i412.1393

Demesouka O.E., Vavatsikos A.P. and Anagnostopoulos K.P. (2014). GIS-based multicriteria municipal solid waste landfill suitability analysis: a review of the methodologies performed and criteria implemented. Waste Manage. Res. 32 (4), 270-296.

DOI: $10.1177 / 0734242 X 14526632$

Fenn D., Hanley K. and DeGeare T. (1975). Use of the water balance for predicting leachate concentration from solid waste disposal sites. EPA-530/SW-168, United States environmental protection agency, Cincinnati, USA, 45 pp.

Friedrich E. and Trois C. (2011). Quantification of greenhouse gas emissions from waste management processes for municipalities - A comparative review focusing on Africa. Waste Manage. 31 (7), 1585-1596.

DOI: $10.1016 /$ j.wasman.2011.02.028

Gallardo A., Carlos M., Peris M. and Colomer F.J. (2014). Methodology to design a municipal solid waste generation and composition map: A case study. Waste Manage. 34 (11), 1920-1931.

DOI: 10.1016/j.wasman.2014.05.014

Gallardo-Izquierdo A. and Bernard-Beltrán D. (2011). Aplicación de los sistemas de información geográfica (SIG) a la gestión de los residuos. Diseño de una herramienta para la recogida selectiva. In: Residuos sólidos: un enfoque multidisciplinario (L. MárquezBenavides, Ed.). Libros en red, Buenos Aires, Argentina, pp. 613-637.

Gbanie S.P., Tengbe P.B., Momoh J. S., Medo J. and Kabba V.T.S. (2013). Modelling landfill location using geographic information systems (GIS) and Multi-Criteria Decision Analysis (MCDA): Case study Bo, Southern Sierra Leone. Appl. Geogr. 36, 3-12.

DOI: 10.1016/j.apgeog.2012.06.013

González-Cruz R. (2013). Diagnóstico de las condiciones actuales de operación de los sitios de disposición final del Estado de México. Tesis de Licenciatura. Unidad Profesional Interdisciplinaria de Biotecnología, Instituto Politécnico Nacional. Mexico City, Mexico, 79 pp.

INEGI (2012). Censo Nacional de Gobiernos Municipales y Delegacionales 2011. Residuos Sólidos Urbanos. Instituto Nacional de Estadística y Geografía [online]. http://www.beta.inegi.org.mx/proyectos/censosgobierno/municipal/cngmd/2011/ 05/05/2014

INEGI (2014). Recursos naturales. Instituto Nacional de Estadística y Geografía [online]. http://www.inegi.org. $\mathrm{mx} / \mathrm{geo} /$ contenidos/recnat/default.aspx 05/05/2014 25/05/2015

INEGI (2017). Cuéntame de México. Información del Estado de México. Instituto Nacional de Estadística y Geografía [online]. http://cuentame.inegi.org. $\mathrm{mx} / \mathrm{monografias} /$ informacion/mex/territorio/clima. aspx?tema $=$ me\&e $=15$ 16/12/2017

INEGI (2018). Edafología. Instituto Nacional de Estadística y Geografía [online]. http://www.beta.inegi. org.mx/temas/mapas/edafologia/ 16/10/2018

Kiss-Köfalusi G. and Encarnación-Aguilar G. (2006). Los productos y los impactos de la descomposición de residuos sólidos urbanos en los sitios de disposición final. Gaceta Ecológica (México) 79, 39-51.

LGPGIR (2003). Ley General para la Prevención y Gestión Integral de los Residuos. Diario Oficial de la Federación. 8 de octubre de 2003. Mexico City, Mexico.

Marín L.E., Torres V., Bolongaro A., Reyna J.A., Pohle O., Hernández-Espriú A. and Tabla H.F.P. (2012). Identifying suitable sanitary landfill locations in the state of Morelos, México, using a geographic information system. Phys. Chem. Earth 37-39, 2-9.

DOI: $10.1016 /$ j.pce.2011.12.003

Wicander R., Monroe J.S. and Pozo-Rodríguez M. (2008). Aguas subterráneas. In: Geología. Dinámica y evolución de la tierra. 4th ed. (C.M. De la Fuente-Rojo, Ed.). Paraninfo, Madrid, España, pp. 354 -381.

Núñez-Espinoza J.F., Tisselli-Vélez E. and RoblesMartínez F. (2013). Red de Residuos del Valle de México. Mapa Interactivo sobre SDF en el Estado de México [online]. http://evalplandesru.colpos.mx/ about.php\#about 30/11/2014

Robles-Martínez F. (2008). Generación de biogás y lixiviados en los rellenos sanitarios. $2 \mathrm{a}$ ed. Instituto Politécnico Nacional. Mexico City, Mexico, 115 pp.

US-EPA and SCS (2009). EP-W-06-023. Manual del Usuario Modelo Mexicano de Biogás, Versión 2.0. United States Environmental Protection Agency and SCS Engineers. Manual. Reston, EUA, 35 pp.

SEDEMA (2006). Gestión ambiental del aire en el Distrito Federal 2000-2006. Secretaría del Medio Ambiente del Gobierno de la Ciudad de México [online]. http://www. aire.cdmx.gob.mx/descargas/publicaciones/gestionambiental-aire-memoria-documental-2001-2006/ descargas/gaa_avances_propuestas_2000_2006.pdf 25/04/2017

SEDEMA (2014). Inventario de residuos sólidos de la Ciudad de México 2013. Secretaría del Medio Ambiente del Gobierno de la Ciudad de México [online]. https://www.sedema.cdmx.gob.mx/storage/app/media/ programas/residuos-solidos/inventario-residuossolidos-2013/IRS-2013-Final-24-10-14-optimizado. pdf 25/04/2017

SEMARNAT (2003). NOM-083-SEMARNAT-2003. Especificaciones de protección ambiental para la selección del sitio, diseño, construcción, operación, monitoreo, clausura y obras complementarias de un 
sitio de disposición final de residuos sólidos urbanos y de manejo especial. Diario Oficial de la Federación. 20 de octubre de 2004. Mexico City, Mexico.

Shibata T., Wilson J.L., Watson L.M., Nikitin I.V., Ansariadi, La Ane R. and Maidin A. (2015). Life in a landfill slum, children's health, and the millennium development goals. Sci. Total Environ. 536, 408-418.

DOI: $10.1016 /$ j.scitotenv.2015.05.137
Tchobanoglous G. (1998). Gestión integral de residuos sólidos. McGraw Hill/Interamericana de España. Madrid, España, 1115 pp.

Zamorano M., Molero E., Hurtado Á., Grindlay A. and Ramos Á. (2008). Evaluation of a municipal landfill site in Southern Spain with GIS-aided methodology. J. Hazard. Mater. 160 (2-3), 473-481. DOI: 10.1016/j.jhazmat.2008.03.023 